\title{
TECHNICAL TERMS IN BIBLICAL HEBREW?
}

By Roger w. Cowley

In works commenting on the Hebrew Scriptures various Hebrew words are sometimes stated to be 'technical terms', or to be used in 'technical senses'. This study aims to explore (i) whether 'technicity' can be adequately defined, (ii) whether alleged technicity has formed a basis for illogical argument, and (iii) whether there are avenues for further research.

I commence inductively with a random collection of samples of words said to be 'technical':

1. On ריב in Isaiah 41:21-22a, "to set forth the case" ( $r \overline{\mathrm{z} b}$ is a technical term for a process) ...'.2

2. On Esther 8:10 (רמכים), Proverbs 7:16 (אטון), Nahum 2:4 (פלדות) and 2 Kings 6:25 (דביונים), 'An additional four such cases [of hapax legomena] entail the use of clearly technical terms'. 3

3. On מבול in Genesis, 'Mabbūl does not mean "flood", "inundation", or even "destruction", but it is a technical term for a part of the world structure, namely, the heavenly ocean'. 4

4. On the in Leviticus, 'The technical term for the peace offering is in Hebrew zebah'. 5

1. The lecture as given contained an introductory section acknowledging my debt to James Barr's writings, and emphasizing the problems of detecting nuances of meaning in ancient languages when ambiguities and misunderstandings are not uncommon in the speech even of related speakers of the same modern language.

2. C. Westermann, Isaiah 40-66 (London: SCM, 1969) 83.

3. F. E. Greenspahn, 'Hapax Legomena in Biblical Hebrew', VT 30 (1980) 12 .

4. G. von Rad, Genesis (London: SCM, 1972) 128.

5. M. Noth, Leviticus (London: SCM, 1965) 30; same wording in revised trans., 1977. 
5. On שנא in Judges 15:2, 'The latter is based on the technical term used in matters of divorce (Deut. 24.3)'.6

6. 'Sometimes one noun (of a pair of homonyms) belongs to a fairly general semantic field, while another is much more technical, being the name of an animal, an instrument, a measure, or the like. This applies to pairs like אנקה "crying" and אנקה "ferret, shrewmouse"; דרור "release" and דרור "swallow"; (and "daughter" and "בת "(the measure) bath") '.7

7. In his commentary on Kings, J. Gray refers to a number of words as 'the technical words for vessels in the old Testament', 8 and these words are contained in an article by A. M. Honeyman ${ }^{9}$ (which does not refer to them as 'technical').

To these may be added samples of words said to have a particular 'technical use':

1. מקום. 'The indications are that māqōm frequently has a technical meaning and this suggests that the primary reference in this passage [i.e. Jeremiah 33:10-13.] too is to the Temple'.10

2. 'קרב. (The root qrb) should be considered as a technical legal term'. 11

6. R. G. Boling, Judges (New York: Doubleday, 1975) 235.

7. J. Barr, Comparative Philology and the Text of the old Testament (Oxford: OUP, 1968) 146.

8. I and II Kings (London: SCM, $1977^{3}$ ) 381.

9. 'The Pottery Vessels of the Old Testament', PEQ 1939, 76-90.

10. P. R. Ackroyd, Exile and Restoration (London: SCM, 1968) 156, with a footnote referring to the usage of 'Ir 'city', but also meaning 'sanctuary'.

11. Y. Hoffmann, 'The root $Q R B$ as a legal term', Journal of North-Western Semitic Languages 10 (1982) 62-73 (with reference to the trial speeches of Isa. 40-66). 
3. רูif etc. 'Hebrew participial forms like ŠOMER, HOZE, ŠOPET, MAZKIR are to be considered as examples of restriction of meaning from "one who keeps", "one who sees, judges, reminds" to a technical sense "watchman", "seer", "judge", "secretary". . 12

4. גאל etc. and 'Legal terminology like GA'AL "to redeem", PADA "to ransom", ŠAPAT "to judge" and SSEDQ "justice" have been extended in application to non-technical contexts. HOSIA 6 may be an example of an extension of meaning so complete that traces of its original technical application are rare in OT Hebrew. '13

5. ת תכלנה in Genesis 6:16. '[It means] terminating. For similar technical use of the verb, see Exod. xxvi.24.114

In addition to these examples, ${ }^{15}$ the literature on biblical and theological studies contains many references to 'technical terms' in which the actual words are unspecified, e.g. the 'many technical terms' in the account of the building of the Temple, 1 Kings 6-7, 16 the 'technical terminology of revelation', 17 the 'technical or individual things' listed e.g. in

12. J. F. A. Sawyer, Semantics in Biblical Research (London: SCM, 1972) 55.

13. Ibid.

14. E. A. Speiser, Genesis (New York: Doubleday, 1964) 52; his reference to Ex. 26:24 is incorrect.

15. The lecture as delivered gave further examples from post-Biblical Hebrew (see e.g. E. Y. Kutscher, $A$ History of the Hebrew Language [Leiden: Brill, 1982] 57 and 241-242; Barr, Comparative Philology 204, 237; various dictionaries of 'technical terms' [ו מחני] [טכניקה produced by the Hebrew Language Academy), and from NT Greek (see e.g. D. Daube, ' $x \varepsilon \rho \delta \alpha i v \omega$ as a missionary term' HTR 40 [1947] 109-120; R. T. France, 'Exegesis in Practice: Two Samples', in New Testament Interpretation, ed. I. H. Marshall [Exeter:

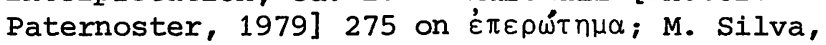
Biblical Words and their Meaning [Grand Rapids: Zondervan, 1983] $151 \mathrm{n.34)}$.

16. Gray, I and II Kings 157.

17. J. Painter, John: Witness and Theologian (London: SPCK, 1975) 25. 
Leviticus 11, Deuteronomy 14, Ezekiel $27^{18}$, and the technicity of 'legal terminology in the wisdom literature'. 19

These examples of alleged technical terms show that they are a curious collection, ranging from common words like פקום and to hapax legomena like תלדות which are so obscure that no definite statements can be made about them. It appears that the authors cited lack a common criterion of technicity, and that the words cited range from familiar to unfamiliar ones along a spectrum so continuous that there is no obvious cut-off point.

Most works on general linguistics do not offer a formal definition of 'technical term'.20 But the following quotations give some indications of usage.

1. 'Belonging or relating to an art or arts; appropriate or peculiar to, or characteristic of, a particular art, science, profession, or occupation ...' (Oxford English Dictionary).

2. 'What distinguishes technical terminology is that the named things are specialized categories, and it is because the categories are found to be needed ... that specialized terms arise.'

'The clearest signals of a particular register are scientific technical terms, except those that belong to more than one science like 'morphology' in biology and linguistics. 21

18. M. Schloessinger, 'Hapax Legomena', Jewish Encyclopedia, vol. 6, ed. I. Singer et al. (London: Funk \& Wagnalls, 1904) 226.

19. H. Rabin, בית מקרא התיתכן סמנטיקה מקראית Jerusalem, 1972, 17-27, especially 'the question whether the legal terminology in the wisdom literature functions as a technical terminology (מינוח טכני) or whether, in the non-technical context, it has already lost its sharpness of meaning' .

20. This fact illustrates the gulf between linguistics and theology. Similarly, there is not, in the study of stylistics, a generally agreed definition of 'genre' (D. Crystal and D. Davy, Investigating English Style [London: Longman, 1969] 75).

21. M. A. K. Halliday, A. McIntosh, and P. Strevens, The Linguistic Sciences and Language Teaching (London, 1964) 7, 88 .

https://tyndalebulletin.org | https://doi.org/10.53751/001c.30565 
3. 'Terms belonging to a technology.' 'The more technical a term, the more esoteric its use; negatively, the more numerous the competent speakers who do now know it.' 22

4. 'It is usual to regard as technical terms only those words which appear to have a very precise reference ... But "exactness" of meaning is a tricky thing to calculate, and since this kind of classification tends to bring in value judgements as well it is probably best avoided for stylistic purposes, where the points at issue are whether a word is unique to a province, or, if not unique, whether it is used there in a special way. 123

It appears that 'technical terms' are generally understood to be those terms that are characteristic of a province/register/sphere/field/domain. This raises (i) the problem of defining provinces/registers etc., and (ii) the spectre of circularity of argument. On (i), Sawyer defines 'register' as 'the variety of language proper to a particular situation'; ${ }^{24}$ Crystal and Davy write that 'province' refers to 'the features of language which identify an utterance with those variables in an extra-linguistic context which are defined with reference to the kind of occupational or professional activity being engaged in'. 25 On (ii), it is clearly fallacious to argue that: (a) $x$ is a technical term because it occurs in province/register/context $A$, and (b) $A$ is an example of a certain type of province because it contains the word $x$. There follows the danger of a further circular argument: (a) $x$ is $a$ technical term, therefore (b) in context $A$ it must have a certain specified meaning. From this it is only a short step for the student to make the assumption that 'technical terms' are 'marked' (i.e. are morphologically distinguishable).

22. B. M. H. Strang, A History of English (London: Methuen, 1970) 87-88.

23. Crystal and Davy, English Style 210.

24. Semantics 17.

25. English Style 71, also quoted by J. Lyons, Semantics (Cambridge: CUP, 1977) 582 . 
If 'technical terms' are words unique to a province/register, the question immediately arises: 'What are the provinces/registers of Biblical Hebrew?' It is doubtful whether extant Biblical Hebrew literature constitutes a corpus sufficiently large or varied for this question to be investigated. Sawyer has chosen as one register 'the language of people addressing their God', 26 but this leaves open the question of whether the languages of a person addressing a child/superior/wife/ father-in-law etc. should be considered as further separate registers, and, if so, how far distinctions should be taken. 27

Against the background of these considerations, three of the examples given above will be analysed in more detail.

1. מוק. In support of the technical meaning 'shrine', P. R. Ackroyd, writing on Jeremiah $33: 10-13,{ }^{28}$ cites an article of $\mathrm{J}$. E. Browne 29 in which Browne asks of Ezra 8:17, "May it not be that מקום has here the meaning of "sanctuary"? We know that in early times the word was used as equivalent to the Arabic maqām meaning "a shrine".' Browne in turn cites an article of A. E. Cowley, ${ }^{30}$ who says of Genesis $12: 6 ; 13: 14 ; 22: 4$ and 28:11, 'As the text stands some special meaning is required for מקום. In modern Palestine the corresponding word (Arabic) maqām is the proper term for a sacred spot under the protection of a nabì' or walî...'

This argument is further developed in the TDNT article on $\tau o$ íos, but it must be queried on the grounds (i) that the Arabic parallel is irrelevant to the meaning in Hebrew, and (ii) it is unclear why this should be referred to as 'a technical usage'.

J. Barr has stated the matter more precisely: 'there are certainly places where Canaanite and Aramaic inscriptions use a word cognate with Hebrew מקום, and where the reference is to a place of burial. It does not

26. Semantics 18 .

27. See Crystal and Davy, English Style 71-72.

28. Exile and Restoration 156.

29. 'A Jewish Sanctuary in Babylonia', JTS 17 (1916) 400-401.

30. 'The meaning of מקום in Hebrew', JTS 17 (1916) 174-176. 
follow that this word communicates the specific information "tomb, grave, place of burial". Rather, the writers, referring to a tomb or the area around it, called it a "place". 31

2. רע. Ackroyd 32 implies that a meaning 'sanctuary' is a technical meaning. He cites an article of $\mathrm{L}$. R. Fisher ${ }^{33}$ which actually says not that ' $I r$ is a common word with an additional specific technical meaning, but that "sîr is a flexible term meaning not only village, city or state, but that it can also have the meaning of temple quarter or even of the inner room of the temple'.

3. מבול. Von Rad states that in Genesis this is a terminus technicus for the heavenly ocean, and cites an article of J. Begrich. ${ }^{34}$ Begrich's argument is that attempts to explain the word mabbul on the basis of the languages and literatures that influenced the early Hebrews are inconclusive, and that the word should be understood on the basis of the occurrence in Hebrew in the Psalms (Psalm 29:10) as a terminus technicus for the heavenly ocean; he further suggests Babylonian influence on Psalm 29. 35

Begrich's argument, and therefore von Rad's, is open to these criticisms:

(a) that it is not clear why this is called a terminus technicus - it does not appear to be 'unique to a province', or 'unknown to the majority of speakers';

31. Comparative Philology 292, also referred to in A. Gibson, Biblical Semantic Logic (Oxford: Blackwell, 1981) 50.

32. Exile and Restoration 156.

33. 'The Temple Quarter', JSS 8 (1963) 34-41.

34. 'Mabbūl. Eine exegetisch - lexikalische Studie', Zeitschrift für Semitistik (1928) 135-153.

35. Since then, of course, the close link of Ps. 29 with Ugaritic texts has been investigated - see e.g. F. M. Cross, 'Notes on a Canaanite Psalm in the old Testament', BASOR 117 (1949) 19-21. 
(b) no reason is advanced for supposing that the meaning of eleven occurrences of מבול in Genesis, where it appears from the context to mean a flood of water, should be determined by a possible meaning of the only other occurrence of the word in the Hebrew Bible; and

(c) the adducing of non-Israelite parallels is of interest for comparative mythology - but does not elucidate what the members of the communities actually thought (indeed, as J. Barr has remarked in another context, ${ }^{36}$ it is actually 'anti-comparative' in its effects).

\section{Conclusions}

1. 'Technical term' is used rather loosely in Biblical commentaries, and is not a defined term of linguistic science. ${ }^{37}$

2. Arguments based on alleged technicity are likely to be ill-founded and/or circular.

3. There is a need for further investigation of the registers/provinces of Biblical Hebrew.

36. Comparative Philology 292.

37. A recent study which successfully avoids the hazards outlined above is N. Tidwell's Oxford B.D. dissertation (1982, : unpublished), '"A Highway for our God." A Study of the Meaning and Associations of the word nob in the old Testament.' 